\title{
A Study on the Economic Activities of Farm Households in the Sub-tropics of Jammu, India
}

\author{
Fatima Bano $^{1 *}$, Rakesh Nanda ${ }^{1}$, Rajinder Peshin ${ }^{1}$ and Rizwan Jeelani ${ }^{2}$ \\ ${ }^{1}$ Division of Agricultural Extension Education, SKUAST-Jammu, India \\ ${ }^{2}$ Division of Veterinary Extension, F.VSc. and A.H., SKUAST-Jammu, India \\ *Corresponding author
}

\begin{tabular}{|l|}
\hline Ke y w o r d s \\
Agriculture, \\
$\begin{array}{l}\text { Economic activity, } \\
\text { Employment, Farm } \\
\text { households }\end{array}$ \\
\hline Article Info \\
\hline $\begin{array}{l}\text { Accepted: } \\
\text { 17 June } 2019 \\
\text { Available Online: } \\
\text { 10 July } 2019\end{array}$ \\
\hline
\end{tabular}

\section{A B S T R A C T}

The study was undertaken to analyse the economic activities of farm households in the sub-tropics of Jammu region of Jammu \& Kashmir state and whether farm households depend exclusively on agriculture for their livelihood or not. The study was conducted by employing non-experimental descriptive research design. Multi stage sampling technique was applied for selecting a total sample of 370 farmers: 270 rice-wheat cultivating farmers from Jammu, Samba and Kathua districts and 100 vegetable cultivating farmers from Jammu district. The data were collected from the respondents by using the pre-tested interview schedule by means of faceto-face/personal interview method. The results revealed that, only 22 per cent ricewheat farmers and 13 per cent vegetable farmers (households) dependent exclusively on agriculture related activities for their livelihood. The share of offfarm economic activities was 78 and 87 per cent in rice-wheat and vegetable farm households, respectively which included: government employment, private employment, retired from employment, business/shopkeeper, and casual labourer among others. It is clear that for most of the farm households in the sub-tropics of Jammu, farming is not the sole and primary economic activity and agriculture is not providing economic security to the rice-wheat and vegetable farmers.

\section{Introduction}

Agriculture is the principal source of livelihood for almost half of the world's population and is one of the prevalent types of employment generator in the world (Anonymous, 2010). Nearly 50 per cent of world's labour is employed in agriculture and it has risen from 6 billion to 9 billion (Anonymous, 2010). In India also, agriculture provides livelihood to a majority of population even today (Anonymous, 2011). Agriculture is the principal source of livelihood for 48 per cent of the population of India and accounts for about 15.4 percent of Gross Domestic Product (GDP) (MoSPI, 2018-19). It provides the bulk of wage goods required by nonagriculture sectors and most of the raw material for the industrial sector. Although the share of agriculture in the Indian GDP has 
seen a declining trend over the decades (from 55.4 per cent in $1950-51$ to 15.4 per cent in 2018-19), the importance of agriculture in Indian economy cannot be negated. Agriculture and allied sector has a critical role in ensuring food security, reducing poverty and sustaining growth in India (ES, 2017-18). In the state of Jammu and Kashmir also, the share of agriculture continues to decline too, as over the past decade its contribution to the state's gross domestic product (GDP) has fallen by 8 percent (www.kashmirreader.com). According to the Draft Srinagar Master Plan 2035, the share of agriculture has dipped from 28 per cent to 16 per cent and is the weakest contributor in the draft master plan but it continues to provide employment to 60 percent of the population of Jammu and Kashmir. Thus, the fact cannot be negated that agriculture is largest employer and the primary driver of the economy of the state as well as the country.

In the present study an attempt has been done to analyse the economic activities of farm households in the sub-tropics of Jammu region of Jammu \& Kashmir state and whether farm households depend exclusively on agriculture for their livelihood or not.

\section{Materials and Methods}

The state of Jammu and Kashmir is situated in North West Himalayan region extending over $32^{\circ} 17^{\prime}$ and $36^{\circ} 58^{\prime}$ North latitude and $73^{\circ} 26^{\prime}$ and $80^{\circ} 30^{\prime}$ 'East longitudes. Jammu region has 10 districts falling in temperate and subtropics. The sub-tropical region of the Jammu province constitutes the entire Jammu district, part of Samba, Kathua, Udhampur, and Rajouri districts. The sample for the study consisted of irrigated as well as rain-fed areas of Jammu, Samba and Kathua districts. The irrigated belt comprised of rice and wheat cultivating areas of Jammu district (Marh, R.S. Pura, and Bishnah), Samba district
(Vijaypur, Samba, and Gaghwal) and Kathua district (Hiranagar, and Kathua). On the other hand, the rain-fed belt comprised of Basholi block of Kathua district. Further, vegetable cultivating areas of Marh, R.S. Pura, and Bishnah of Jammu district were selected for the study. The research design employed for the study was non-experimental descriptive research design. Multi stage sampling technique was applied for selecting a total sample of 270 rice-wheat cultivating farmers from Jammu, Samba and Kathua districts and 100 vegetable cultivating farmers from Jammu district. The data were collected from the respondents by using the pre-tested interview schedules by means of personal interview method.

\section{Results and Discussion}

The respondent rice-wheat and vegetable cultivating farmers were matching in almost all parameters of socio-economic and biophysical variables of age, education, experience, family size, land ownership and distance (Table 1). The significant difference between the rice/wheat and vegetable cultivating farmers was in the case of biophysical variables namely average operational land holding ( $\mathrm{t}=2.48, \mathrm{p}=0.01)$, owned land holding $(\mathrm{t}=2.53, \mathrm{p}=0.01)$, irrigated $(\mathrm{t}=3.95$, $\mathrm{p}=0.00)$ and unirrigated land holding $(\mathrm{t}=6.28$, $\mathrm{p}=0.29)$, average fragments of land $(\mathrm{t}=2.95$, $\mathrm{p}=0.00$ ), and distance of village from Department of Agriculture $(\mathrm{t}=5.37, \mathrm{p}=0.00)$ and Krishi Vigyan Kendra $(\mathrm{t}=2.10, \mathrm{p}=0.03)$ (Table 1).

\section{Economic activities of farm households in the sub-tropics of Jammu}

The results presented in Table 2 reveal that the total family size in case of rice-wheat famers was 1720 individuals and workforce comprised of 72 per cent of the total family size. 
Table.1 Descriptive statistics of the sampled groups of rice-wheat and vegetable farmers

\begin{tabular}{|c|c|c|c|c|c|}
\hline Parameter & $\begin{array}{c}\text { Rice and } \\
\text { wheat farmers } \\
(\mathbf{n = 2 7 0})(\mathbf{I})\end{array}$ & $\begin{array}{c}\text { Vegetable } \\
\text { farmers } \\
(\mathbf{n = 1 0 0})(\mathbf{J})\end{array}$ & $\begin{array}{l}\text { Diff. } \\
\text { (I-J) }\end{array}$ & d.f & $\begin{array}{l}\text { Statistic } \\
\text { (p value) }\end{array}$ \\
\hline Mean age(years) & $54.7 \pm 14.3$ & $55.1 \pm 13.1$ & 0.4 & 368 & $\mathrm{t}=0.22(0.82)$ \\
\hline $\begin{array}{l}\text { Mean education(formal number } \\
\text { of schooling years completed) }\end{array}$ & $7.8 \pm 3.9$ & $7.0 \pm 3.8$ & 0.8 & 368 & $\mathrm{t}=1.69(0.09)$ \\
\hline $\begin{array}{l}\text { Average farming experience } \\
\text { (years) } \\
\text { Average experience in vegetable } \\
\text { cultivation(years) }\end{array}$ & $\begin{array}{c}36.6 \pm 17.0 \\
-\end{array}$ & $\begin{array}{l}35.8 \pm 15.7 \\
30.8 \pm 13.1\end{array}$ & $\begin{array}{c}0.8 \\
-\end{array}$ & $\begin{array}{r}368 \\
-\end{array}$ & $\begin{array}{c}\mathrm{t}=0.37(0.70) \\
-\end{array}$ \\
\hline $\begin{array}{l}\text { Average family size (No.) } \\
\text { i) Average number of adults } \\
\text { ii) Average number of children }\end{array}$ & $\begin{array}{l}6.3 \pm 3.0 \\
4.59 \pm 1.7 \\
1.74 \pm 1.8\end{array}$ & $\begin{array}{l}6.2 \pm 2.5 \\
4.46 \pm 1.6 \\
1.78 \pm 1.4\end{array}$ & $\begin{array}{c}0.1 \\
0.13 \\
0.04\end{array}$ & $\begin{array}{c}368 \\
368 \\
216.155\end{array}$ & $\begin{array}{l}t=0.41(0.67) \\
t=0.68(0.49) \\
t=0.03(0.97)\end{array}$ \\
\hline $\begin{array}{l}\text { Family type (\% households) } \\
\text { Nuclear } \\
\text { Joint }\end{array}$ & $\begin{array}{l}61 \\
39\end{array}$ & $\begin{array}{l}57 \\
43\end{array}$ & $\begin{array}{l}4.0 \\
4.0\end{array}$ & - & $\begin{array}{l}Z=0.69(0.48) \\
Z=0.69(0.48)\end{array}$ \\
\hline $\begin{array}{l}\text { Average operational land } \\
\text { holding(ha) } \\
\text { A. Based on ownership (ha) } \\
\text { Owned } \\
\text { Leased in } \\
\text { Leased out } \\
\text { B. Based on irrigation (ha) } \\
\text { Irrigated } \\
\text { Unirrigated }\end{array}$ & $\begin{array}{c}1.55 \pm 1.39 \\
0.21 \pm 1.28 \\
0.005 \pm 0.06 \\
\\
1.37 \pm 1.4 \\
0.39 \pm 0.9\end{array}$ & $\begin{array}{c}1.26 \pm 1.38 \\
1.16 \pm 1.26 \\
0.13 \pm 0.53 \\
0.03 \pm 0.18 \\
1.25 \pm 1.38 \\
0.008 \pm 0.04\end{array}$ & $\begin{array}{r}0.4^{*} \\
0.09 \\
0.015 \\
\\
0.07^{*} \\
0.373^{*}\end{array}$ & $\begin{array}{c}368 \\
\\
368 \\
368 \\
108.734 \\
102.737 \\
272.358\end{array}$ & $\begin{array}{l}t=2.48(0.01) \\
t=2.53(0.01) \\
t=0.64(0.51) \\
t=1.06(0.29) \\
t=3.95(0.00) \\
t=6.28(0.00)\end{array}$ \\
\hline $\begin{array}{l}\text { Categorization of farm size } \\
\text { (\% farmers) } \\
\text { i) Marginal (<1ha) } \\
\text { ii) Small (1-2ha) } \\
\text { iii) Semi medium (2-4ha) } \\
\text { iv) Medium (4-10ha) } \\
\text { v) Large (>10ha) }\end{array}$ & $\begin{array}{r}37 \\
34 \\
23 \\
4 \\
1\end{array}$ & $\begin{array}{r}40 \\
26 \\
28 \\
5 \\
1\end{array}$ & $\begin{array}{l}3.0 \\
8.0 \\
5.0 \\
1.0 \\
0.0\end{array}$ & $\begin{array}{l}- \\
- \\
- \\
- \\
-\end{array}$ & $\begin{array}{c}Z=0.52(0.59) \\
Z=1.46(0.14) \\
Z=0.99(0.31) \\
Z=0.42(0.67) \\
-\end{array}$ \\
\hline $\begin{array}{l}\text { Average fragments of land } \\
\text { holding }\end{array}$ & $3.12 \pm 1.98$ & $2.41 \pm 2.28$ & $0.71 *$ & 368 & $\mathrm{t}=2.95(0.00)$ \\
\hline $\begin{array}{l}\text { Land ownership (\% farmers) } \\
\text { Sole ownership } \\
\text { Joint ownership }\end{array}$ & $\begin{array}{l}86 \\
14\end{array}$ & $\begin{array}{l}86 \\
14\end{array}$ & $\begin{array}{l}0.0 \\
0.0\end{array}$ & $\begin{array}{l}- \\
-\end{array}$ & - \\
\hline $\begin{array}{l}\text { Average distance (km) of village } \\
\text { from: } \\
\text { i) Department of Agriculture } \\
\text { ii) KrishiVigyan Kendra } \\
\text { iii) Fertilizer dealer } \\
\text { iv) Pesticide dealer } \\
\text { v) Nearest market }\end{array}$ & $\begin{array}{l}5.92 \pm 4.66 \\
18.9 \pm 19.8 \\
2.22 \pm 1.46 \\
2.22 \pm 1.46 \\
2.99 \pm 1.30\end{array}$ & $\begin{array}{c}4.1 \pm 1.78 \\
21.8 \pm 6.34 \\
2.3 \pm 2.17 \\
2.3 \pm 2.17 \\
3.2 \pm 1.75\end{array}$ & $\begin{array}{l}1.82^{*} \\
2.9^{*} \\
0.08 \\
0.08 \\
0.21\end{array}$ & $\begin{array}{l}367.578 \\
363.184 \\
133.575 \\
133.575 \\
140.876\end{array}$ & $\begin{array}{l}t=5.37(0.00) \\
t=2.10(0.03) \\
t=0.43(0.66) \\
t=0.43(0.66) \\
t=1.18(0.23)\end{array}$ \\
\hline
\end{tabular}


Table.2 Economic activities of rice/wheat and vegetable growing farm households ${ }^{1}$

\begin{tabular}{|c|c|c|c|c|}
\hline Parameter & $\begin{array}{c}\text { Rice and } \\
\text { wheat farmers } \\
(\mathbf{n}=\mathbf{2 7 0}) \\
(\mathbf{I})\end{array}$ & $\begin{array}{c}\text { Vegetable } \\
\text { farmers } \\
(\mathbf{n}=100) \\
(\mathbf{J})\end{array}$ & $\begin{array}{l}\text { Difference } \\
\text { (I-J) }\end{array}$ & $\begin{array}{c}\mid Z \text { value } \mid \\
\text { (p value) }\end{array}$ \\
\hline Total family size (No.) & 1720 & 623 & - & - \\
\hline Workforce (\%) & 72 & 72 & 0 & - \\
\hline $\begin{array}{l}\text { Farm households exclusively } \\
\text { dependent on farming (\%) }\end{array}$ & 22 & 13 & 9 & $1.93(0.05)$ \\
\hline $\begin{array}{l}\text { Farm households with on-farm } \\
\text { economic activities }(\%) \\
\text { Field crop income } \\
\text { Livestock income } \\
\text { Fruit crop income } \\
\text { Vegetable crop income }\end{array}$ & $\begin{array}{c}100 \\
100 \\
14 \\
2 \\
0\end{array}$ & $\begin{array}{c}100 \\
100 \\
23 \\
0 \\
100\end{array}$ & $\begin{array}{c}0 \\
0 \\
0 \\
9 * \\
2 \\
100\end{array}$ & $\begin{array}{c}- \\
- \\
2.07(0.03) \\
1.42(0.15) \\
1.64(0.09)\end{array}$ \\
\hline $\begin{array}{l}\text { Farm households with off-farm } \\
\text { economic activities (\%) } \\
\text { Government employment } \\
\text { Private employment } \\
\text { Retired from employment } \\
\text { Business/shopkeeper } \\
\text { Casual labourer } \\
\text { Contractual labourer } \\
\text { MGNREGA }\end{array}$ & $\begin{array}{c}78 \\
32 \\
22 \\
19 \\
15 \\
42 \\
2 \\
7\end{array}$ & $\begin{array}{c}87 \\
\\
24 \\
22 \\
10 \\
17 \\
34 \\
3 \\
3\end{array}$ & $\begin{array}{c}9 \\
\\
8 \\
0 \\
9 * \\
2 \\
8 \\
1 \\
4\end{array}$ & $\begin{array}{l}1.93(0.05) \\
\\
1.49(0.13) \\
- \\
2.06(0.03) \\
0.47(0.63) \\
1.39(0.16) \\
0.57(0.56) \\
1.44(0.14)\end{array}$ \\
\hline $\begin{array}{l}\text { Main occupation of the head of } \\
\text { family (\%) } \\
\text { Agriculture } \\
\text { Government employment } \\
\text { Retired from employment } \\
\text { Private employment } \\
\text { Business/shopkeeper } \\
\text { Casual labourer }\end{array}$ & $\begin{array}{c}66 \\
3 \\
18 \\
4 \\
6 \\
3\end{array}$ & $\begin{array}{c}72 \\
3 \\
13 \\
3 \\
6 \\
3\end{array}$ & $\begin{array}{l}6 \\
0 \\
5 \\
1 \\
0 \\
0\end{array}$ & $\begin{array}{c}1.09(0.27) \\
- \\
1.14(0.25) \\
0.04(0.65) \\
- \\
-\end{array}$ \\
\hline
\end{tabular}

${ }^{1}$ Multiple responses 
Fig.1 Sources of income for rice-wheat cultivating farm households

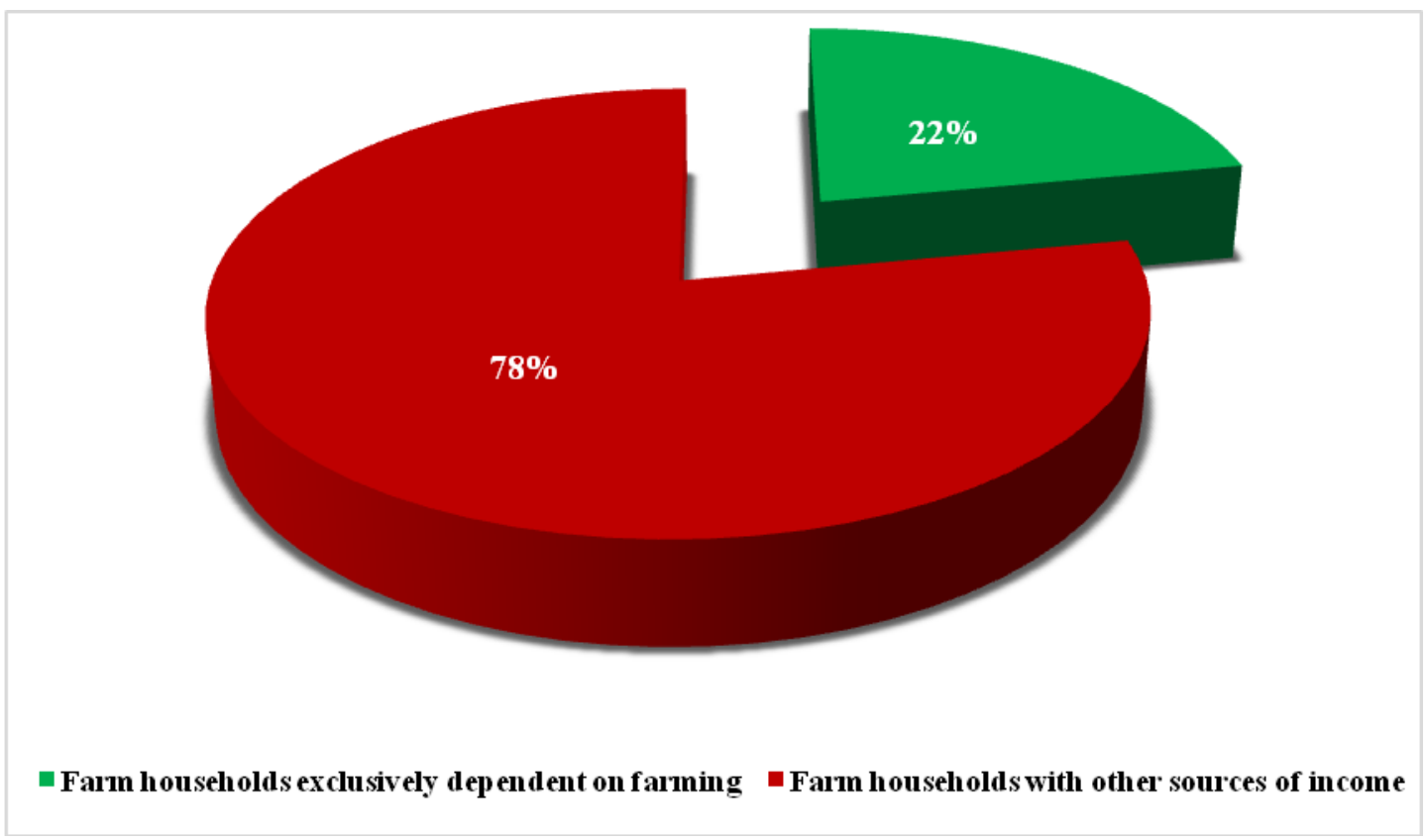

Fig.2 Sources of income for vegetable cultivating farm households

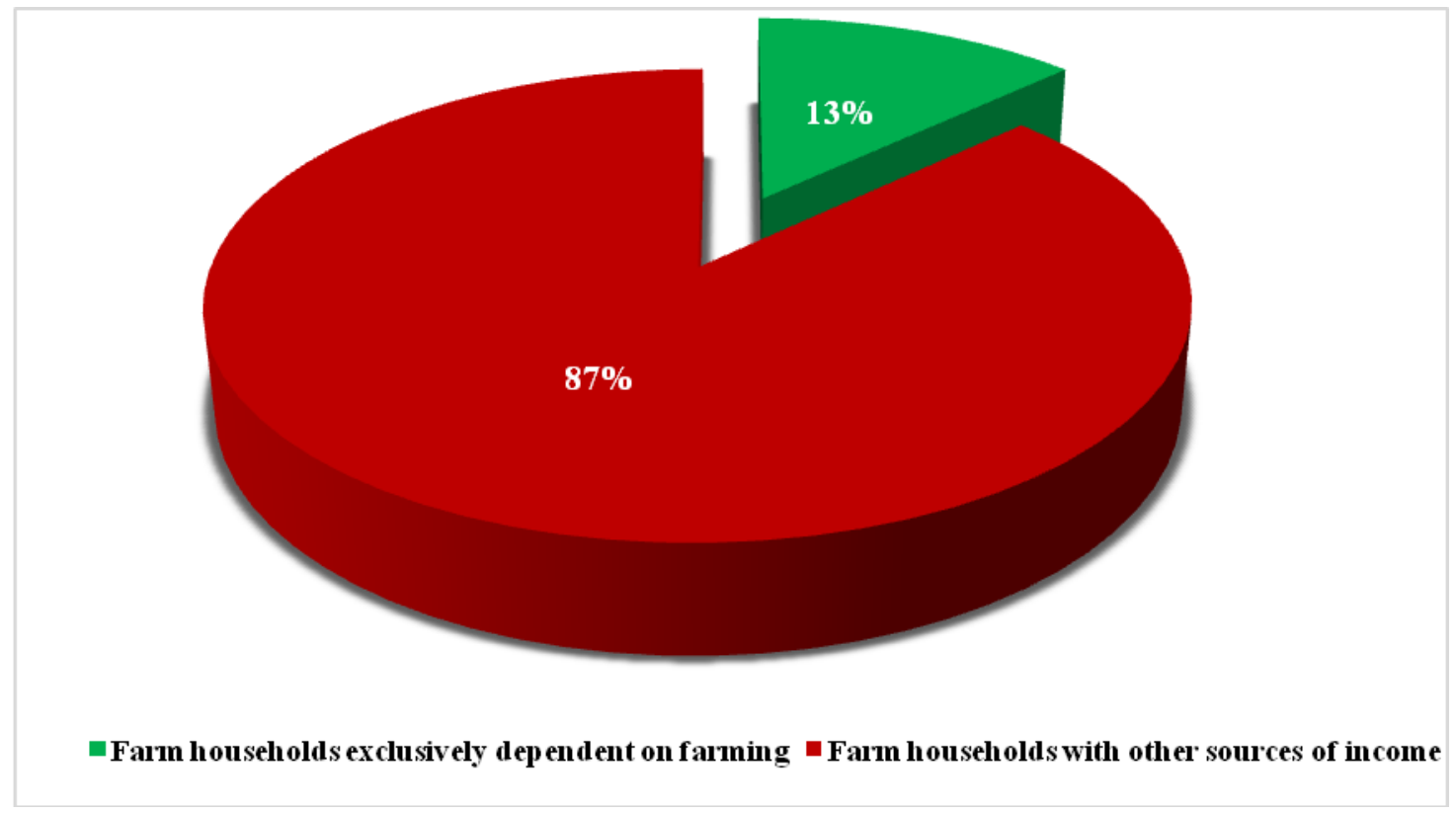

The farm households exclusively dependent on farming (or agriculture as an exclusive source of income) were 22 per cent households (Fig. 1). The on-farm economic activities comprised of income from cultivation of field crops, income from domestication of livestock, and income from cultivation of fruit crops and the percentage of farm households with these economic activities in case of rice-wheat farmers were 100, 14, and 2 per cent respectively. In case of off-farm economic activities, income from 
government job, private employment, retired from employment (pension), business, casual labour, contractual labour and income from MGNREGA (Mahatma Gandhi National Rural Employment Act) were considered and the percentage of rice-wheat farm households with income from these sources was 32, 22, $19,15,42,2$ and 7 per cent respectively. Further, the main occupation of the head of the family was also considered and it was revealed that the occupation of majority of the farmers was agriculture (66\%) followed by retired from government employment (18\%), businessmen $(6 \%)$ and casual labourer $(3 \%)$. It was interesting to note that only three per cent heads of families were government employees.

In case of vegetable growing farmers, the workforce was 72 per cent of the total family size (623 individuals) and only 13 per cent farm households depended exclusively on farming (Fig. 2). In case of on-farm economic activities, 100 per cent households depended each on field crop income and vegetable crop income and 23 per cent household derived income from livestock domestication. The share of off-farm economic activities in case of vegetable growers was 87 per cent, with majority of the share under casual labourer (34\%) followed by government employment $(24 \%)$, private employment $(22 \%)$, business $(17 \%)$ and retired from government employment (10\%) (Table 2). The main occupation of the head of family was agriculture $(72 \%)$ in case of vegetable growers. Further, thirteen per cent heads of families were retired from government employment and only six per cent were businessmen.

A debate has been going on in relation to the actual dependency of farmers on agriculture as a source of livelihood. Contrary to earlier Census Report of 2001, the Census Report of 2011 reported that out of the total population of India, proportion of workers in agriculture sector (cultivators and agricultural labours) declined by 3.6 percent pointsfrom 58.2 per cent in 2001-02 to 54.6 per cent in 2011-12. This study also revealed that, less number of rice-wheat and vegetable cultivating farmers depended exclusively on farming for their livelihood. Only 22 per cent rice-wheat farmers and 13 per cent vegetable farmers (households) dependent exclusively on agriculture related activities for their livelihood. The study is also in conformity with the report of Sainath (2013) that less than 10 per cent of the Indian population is full time cultivators. Peshin et al., also reported in 2014 that only 26 per cent households in Jammu region are exclusively dependent on farming for their livelihood. Bano (2014) and Bano et al., (2016) also reported that only three non-HMNEH households (12\%) and 14 HMNEH households (28\%) depended exclusively on agriculture for their livelihood.

Thus, it can be inferred that although agriculture is considered the most important source of livelihood for farmers, the farm households in the sub-tropics of Jammu do not depend exclusively on farming for their livelihood. For most of the farm households in the sub-tropics of Jammu, farming is not the sole and primary economic activity and agriculture is not providing economic security to the rice-wheat and vegetable farmers.

\section{References}

Anonymous. 2010. Links to International Development. Available at: http://wwf.org.UK/internationaldevelop mentAssessed on 05-06-2019

Anonymous. 2011. Department of Agriculture and Cooperation, Ministry of Agriculture. Annual report. New Delhi: Government of India.

Bano, F. (2014) Adoption of the 
Recommended Technological Innovations by the Mango Orchardists in Jammu and Samba Districts of the Jammu and Kashmir State. M.Sc. thesis. Division of Agricultural Extension Education. Sher-e-Kashmir University of Agricultural Sciences and Technology of Jammu, Chatha, 180009, India.

Bano, F., Peshin, R., Wali, V.K. and Sharma, L.K. 2016. How Policy Intervention Impacted Adoption of Mango (Mangifera indica) Cultivation in Subtropics of Jammu, India? Indian Journal of Ecology, 43 (1): 552-556.

Draft Master Plan, Srinagar Metropolitan Region-2035. Planning for Sustainable Growth and Change. Srinagar Development Authority, N.H. Bypass, Bemina Srinagar.

ES. 2017-18. Economic Survey, Ministry of Finance, Government of India. Oxford University Press, India. ISBN: 9780199489398, 0199489394. https://kashmirreader.com/2017/12/06/agricul ture-in-jk-going-down-fast-now-just-16of-gdp/ Accessed on 12-02-2019.

MoSPI (2018-19) Ministry of Statistics and Programme Implementation, Government of India. www.mospi.gov.in Accessed on 12-022019.

Peshin, R., Sharma, L.K., Sharma, R., Gupta, V., Dwivedi, S. and Nanda, R. 2014. Impact of Government Intervention in Procurement of Wheat and Factors Affecting Wheat Productivity. State Agriculture Management and Extension Training Institute Jammu and Division of Agricultural Extension Education, SKUAST of Jammu.

Sainath, P. 2013. Over 2,000 fewer farmer a everyday. The Hindu, May 2, 2013 (www.thehindu.com/opinion/columns/s ainath/over-2000-fewer-farmerseveryday/article4674 190) accessed on 26-06-2018.

\section{How to cite this article:}

Fatima Bano, Rakesh Nanda, Rajinder Peshin and Rizwan Jeelani. 2019. A Study on the Economic Activities of Farm Households in the Sub-tropics of Jammu, India. Int.J.Curr.Microbiol.App.Sci. 8(07): 2207-2213. doi: https://doi.org/10.20546/ijcmas.2019.807.268 